\title{
PENGEMBANGAN MODUL PERENCANAAN PEMBELAJARAN DALAM PEMBELAJARAN BERBASIS INTEGRATIVE LEARNING DESIGN FRAMEWORK
}

\author{
Abdul Hasan Saragih', Keysar Panjaitan ${ }^{2}$, R. Mursid $^{3}$ \\ Pendidikan Teknik Mesin, Fakultas Teknik, Uniersitas Negeri Medan \\ ahasansaragih@gmail.com ${ }^{1}$, keysarpanjaitan@gmail.com ${ }^{2}$,mursid.tp@gmail.com ${ }^{3}$
}

\begin{abstract}
Abstrak: Penelitian ini bertujuan: (1) Menghasilkan modul perencanaan pembelajaran berbasis integrative learning design framework yang layak digunakan dalam pembelajaran; (2) mengetahui kelayakan modul perencanaan pembelajaran berbasis integrative learning design framework; (3) mengetahui keefektifan modul perencanaan pembelajaran berbasis integrative learning design framework. Penelitian ini merupakan penelitian dan pengembangan (Research \& Development), Penelitian dan pengembangan ini terdiri dari tiga tahap yaitu pra pengembangan modul, pengembangan modul dan penerapan modul dimana penelitian mengacu pada $R$ \& D cycle Borg \& Gall. Penelitian dilakukan di Program Studi Pendidikan Teknik Mesin UNIMED pada matakuliah Perencanaan Pembelajaran dan Pengembangan di semester 3 melalui validasi ahli, uji coba perorangan, ujicoba kelompok kecil, dan ujicoba utama. Hasil penelitian menunjukkan bahwa: (1) menghasilkan modul perencanaan pembelajaran berbasis integrative learning design framework yng digunakan dalam pembelajaran; (2) modul perencanaan pembelajaran berbasis integrative learning design framework layak digunakan dalam pembelajaran; (3) modul perencanaan pembelajaran berbasis integrative learning design framework efektif dapat meningkatkan hasil belajar mahasiswa.
\end{abstract}

Kata Kunci: modul, perencanaan pembelajaran, integrative learning, framework

\begin{abstract}
This study aims: (1) To produce a learning planning module based on an integrative learning design framework that is suitable for use in learning; (2) determine the feasibility of an integrative learning design framework based learning planning module; (3) determine the effectiveness of the learning planning module based on the integrative learning design framework. This research is a research and development (Research \& Development). This research and development consists of three stages, namely pre-module development, module development and module application where the research refers to the Borg \& Gall $R \&$ $D$ cycle. The research was conducted at the Mechanical Engineering Education Study Program of UNIMED in the Learning and Development Planning course in the 3rd semester through expert validation, individual trials, small group trials, and main trials. The results showed that: (1) produced a learning planning module based on the integrative learning design framework used in learning; (2) the learning planning module based on the integrative learning design framework is suitable for use in learning; (3) the learning planning module based on the integrative learning design framework can effectively improve student learning outcomes.
\end{abstract}

Keywords: modules, learning planning, integrative learning, framework

\section{PENDAHULUAN}

Mata Kuliah Perencanaan Pembelajaran dan Pengembangan sebagai salah satu mata pelajaran yang ada pada semua tingkatan jenjang pendidikan yang seharusnya dapat memberikan kontribusi dalam membangun SDA manusia yang berkualitas. Salah satu masalah yang dihadapi pendidikan saat ini adalah lemahnya kualitas proses pembelajaran. Proses pembelajaran masih bersifat hapalan yang berakibat pada lebih mementingkan isi daripada proses (Holmqvist, 2014). Selain itu mahasiswa pun kurang diarahkan pada proses pembelajaran yang menghubungkan materi dengan kehidupan sehari-hari mahasiswa. Hal ini menyebabkan mahasiswa lebih mudah lupa dan tidak bisa menguhubungkan satu konsep dengan konsep yang lain, untuk itu perlu adanya penerapan strategi, modul, metode pembelajaran yang bervariatif salah satunya pembelajaran modul Experiental Learning (Kolb \& Kolb, 2015:435).

Tujuan Perencanaan Pembelajaran dan Pengembangan adalah menguasai sepenuhnya bahan dan materi ajar, metode dan penggunaan alat dan perlengkapan pembelajaran, menyampaikan kurikulum atas dasar bahasan dan mengelola alokasi waktu yang tersedia dan membelajarkan siswa sesuai yang diprogramkan". Berdasarkan pendapat di atas, 
dapat dikemukakan bahwa tujuan perencanaan itu memungkinkan guru memilih metoda mana yang sesuai sehingga proses pembelajaran itu mengarah dan dapat mencapai tujuan yang telah dirumuskan. Bagi guru, setiap pemilihan metoda berarti menentukan jenis proses belajar mengajar mana yang dianggap efektif untuk mencapai tujuan yang telah dirumuskan. Hal ini juga sekaligus mengarahkan bagaimana guru mengorganisasikan kegiatan-kegiatan siswa dalam proses pembelajaran yang telah dipilihnya. Dengan demikian betapa pentingnya tujuan itu diperhatikan dan dirumuskan dalam setiap pembelajaran, agar pembelajaran itu benar-benar dapat mencapai tujuan sebagaiman yang tertuang dalam kurikulum.

Berdasarkan hasil wawancara, kendala yang sering dihadapi oleh para pendidik dalam pelaksanaan modul Experiental Learning adalah memikirkan atau merancang aktifitas pengalaman belajar seperti apa yang harus terjadi pada diri peserta didik baik individu maupun kelompok. Aktifitas pembelajaran harus berfokus pada peserta belajar (student centered learning). Dengan demikian, apa yang harus pendidik lakukan, apa yang harus peserta didik lakukan, apa yang harus pendidik katakan atau sampaikan harus secara detail dirancang dengan baik. Kendala ini dikarenakan beberapa pendidik tidak melaksanakan pembelajaran sesuai dengan tahap pelaksanaan modul Experiental Learning sehingga berdampak pada kesiapan mental pendidik dan ketuntasan materi belajar pada hari itu menjadi tertunda.

Dari pemaparan peneliti di atas, peneliti memahami bahwa modul Experiental Learning ini menjadi salah satu inovasi dalam memenuhi kebutuhan dunia pendidikan saat ini. Oleh karena itu, pelaksanaan pembelajaran modul Experiental Learning harus dipahami secara menyeluruh oleh semua pihak yang terlibat dalam proses pembelajaran. Berdasarkan observasi tersebut, maka peneliti tertarik untuk mengetahui lebih lanjut tentang Perencanaan Pembelajaran dan Pengembangan dengan menggunakan Modul Pembelajaran Experiential Learning Berbasis Integrative Learning Design Framework (ILDF).

Berdasarkan permasalahan tersebut, maka perlu diterapkan modul pembelajaran berbasis pengalaman, yaitu modul experiential learning. Modul ini melibatkan siswa secara langsung dalam masalah dan isu yang dipelajari. Lestari, N. W. dkk. (2014), belajar menurut modul experiential learning merupakan proses penciptaan pengetahuan melalui kombinasi antara mendapatkan pengalaman dan mentransformasi pengalaman Munif \& Mosik. (2009) experiential learning mengajak siswa untuk memandang secara kritis kejadian yang ditemui dalam kehidupan seharihari dan melakukan penelitian sederhana untuk mengetahui apa yang sebenarnya terjadi kemudian menarik kesimpulan bersama.

\section{Perencanaan Pembelajaran dan \\ Pengembangan}

Perencanaan Pembelajaran dan

Pengembangan adalah menguasai sepenuhnya bahan dan materi ajar, metode dan penggunaan alat dan perlengkapan pembelajaran, menyampaikan kurikulum atas dasar bahasan dan mengelola alokasi waktu yang tersedia dan membelajarkan siswa sesuai yang diprogramkan". Berdasarkan pendapat di atas, dapat dikemukakan bahwa tujuan perencanaan itu memungkinkan guru memilih metoda mana yang sesuai sehingga proses pembelajaran itu mengarah dan dapat mencapai tujuan yang telah dirumuskan. Bagi guru, setiap pemilihan metoda berarti menentukan jenis proses belajar mengajar mana yang dianggap efektif untuk mencapai tujuan yang telah dirumuskan. Hal ini juga sekaligus mengarahkan bagaimana guru mengorganisasikan kegiatan-kegiatan siswa dalam proses pembelajaran yang telah dipilihnya. Dengan demikian betapa pentingnya tujuan itu diperhatikan dan dirumuskan dalam setiap pembelajaran, agar pembelajaran itu benar-benar dapat mencapai tujuan sebagaiman yang tertuang dalam kurikulum.

Oemar Hamalik (2001) mengemukakan bahwa pada garis besarnya perencanaan pembelajaran berfungsi sebagai berikut: (1) Memberi guru pemahaman yang lebih jelas tentang tujuan pendidikan sekolah dan hubungannya dengan pembelajaran yang dilaksanakan untuk mencapai tujuan itu; (2) Membantu guru memperjelas pemikiran tentang sumbangan pembelajarannya terhadap pencapaian tujuan pendidikan; (2) Menambah keyakinan guru atas nilai-nilai pembelajaran yang diberikan dan prosedur yang dipergunakan; (3) Membantu guru dalam rangka mengenal kebutuhan-kebutuhan siswa, minat-minat siswa, dan mendorong motivasi belajar; (4) Mengurangi kegiatan yang bersifat trial dan error dalam mengajar dengan adanya organisasi yang baik dan metoda yang tepat; dan (5) Membantu guru memelihara kegairahan 
mengajar dan senantiasa memberikan bahanbahan yang up to date kepada siswa.

Berdasarkan seluruh uraian di atas, maka secara hakiki tujuan yang paling mendasar dari sebuah perencanaan pembelajaran adalah sebagai pedoman atau petunjuk bagi guru, serta mengarahkan dan membimbing kegiatan guru dan siswa dalam proses pembelajaran. Dengan menerapkan experiental learning kepada mahasiswa, diharapkan mampu memberikan pengautan kognitif, metakognitif, berfikir logis, dan kolaboratif, serta konstruktif pemahaman di bidang pembelajaran/pengajaran.

Modul experiential learning adalah suatu modul proses belajar mengejar yang mengaktifkan pembelajar untuk membangun pengetahuan dan keterampilan melalui pengalamannya secara langsung. Dalam hal ini, Experiential learning menggunakan pengalaman sebagai katalisator untuk menolong pembelajar mengembangkan kapasitas dan kemampuan dalam proses pembelajaran.

Mahfudin menyimpulkan bahwa modul Experiential learning dapat didefinisikan sebagai tindakan untuk mencapai sesuatu berdasarkan pengalaman yang secara terusmenerus mengalami perubahan guna meningkatkan keefektifan dari hasil belajar. Tu;juan dari modul ini adalah untuk mempengaruhi murid dengan tiga cara, yaitu: (1) Mengubah struktur kognitif; (2) Mengubah sikap; dan (3) Memperluas keterampilanketerampilan yang telah ada.

Ketiga elemen itu saling berhubungan dan memengaruhi secara keseluruhan, tidak terpisah-pisah, karena apabila salah satu elemen tidak ada, maka kedua elemen lainnya tidak akan efektif.

\section{Integratif Learning Design Framework}

Hakekat e-learning adalah bentuk pembelajaran konvensional yang dituangkan dalam format digital melalui teknologi internet. Sistem ini dapat digunakan dalam pendidikan jarak jauh maupun pendidikan konvensional. Mengembangkan modul pembelajaran online learning tidak sekedar menyajikan materi pelajaran ke dalam internet tetapi perlu dipertimbangkan secara logis dan senantiasa memegang prinsip pembelajaran.

Proses Perencanaan Pembelajaran dan Pengembangan tersebut lebih pada proses pembelajaran yang dilakukan secara terpisah, maksudnya disini berarti antara pendidik dan peserta didik tidak berada dalam satu ruangan yang sama bahkan waktunya pun berbeda. Interaksi pendidik dan peserta didik dilakukan secara langsung maupun tidak langsung, misal dengan melakukan chatting lewat koneksi internet (langsung) maupun dengan berkirim email untuk sekedar mengumpulkan tugas (tidak langsung). Dengan begitu perlu adanya desain pengembangan yang sederhana, personal, cepat, serta unsur hiburan akan menjadikan peserta didik betah belajar di depan internet seolah-olah mereka belajar di dalam kelas.

Saat ini sudah banyak lembaga pendidikan terutama perguruan tinggi yang sudah mulai merintis dan mengembangkan modul pembelajaran berbasis internet dalam mendukung sistem pendidikan konvensional. Namun suatu inovasi selalu saja menimbulkan pro dan kontra. Oleh karena itu sangat perlu dilakukan kajian, penelitian, dan pengembangan modul e-learning. Pada makalah ini akan mengkaji lebih dalam mengenai desain belajar integratif untuk online learning yang lebih dikenal dengan ILDF atau (Integratif Learning Design Framework).

Bonk dan Reynolds (1997), sebagaimana dikutip oleh Mohammed Ally (2004), mengatakan bahwa untuk mendukung pembelajaran jenis pemikiran tingkat tinggi (high order thinking) melalui web, pembelajaran online harus menyediakan berbagai aktifitas menantang yang memungkinkan pemelajar (learner) mengaitkan informasi baru dan lama, menangkap pengetahuan bermakna, dan menggunakan kemampuan metakognitifnya.

Menurut Nada Dabbagh (2005), modul ILDF (Integratif Learning Design Framework) ini dapat digunakan pada berbagai konteks pembelajaran online, termasuk pengembangan $e$-course untuk perguruan tinggi, pelatihan di perusahaan (corporate training), komunitas belajar online, ataupun sistem pendukung kinerja elektronis (electronic performance support system). Secara umum, modul ILDF ini terdiri dari tiga fase pengembangan atau tiga tahapan, yaitu: fase eksplorasi (exploration), realisasi (enactment), dan evaluasi (evaluation). Namun ada juga yang menambahkan satu tahapan lagi yaitu refleksi.

\section{METODE}

Penelitian ini merupakan penelitian dan pengembangan (Research \& Development), Penelitian dan pengembangan ini terdiri dari 
tiga tahap yaitu pra pengembangan modul, pengembangan modul dan penerapan modul dimana penelitian mengacu pada $\mathrm{R} \& \mathrm{D}$ cycle Borg \& Gall (2005), dengan uraian yang telah dimodifikasi dan diselaraskan dengan tujuan dan kondisi penelitian yang sebenarnya.

Modul penelitian pengembangan menurut Borg \& Gall (2003: 271) memiliki sepuluh tahap. Adapun kesepuluh tahapan tersebut adalah: (1) Penelitian dan pengumpulan informasi awal (research and information collection). (2) Perencanaan (planning); (3) Pengembangan format produk awal (develop preliminary form of product) (4) Uji coba awal (preliminary field testing); (5)
Uji coba lapangan (main field testing); Revisi produk utama dilakukan berdasarkan hasil uji coba produk tahap pertama. (6) Uji coba lapangan (operational field testing); Pengujian produk di lapangan disarankan mengambil sampel yang lebih banyak yaitu 30-100 orang responden (5-15 sekolah). (7) Revisi produk (operational produk revision); (8) Uji lapangan (operational field testing); (9) Revisi produk akhir (Final product revision); (10) Desiminasi dan implementasi (Desimination and implementation).

Tahapan dalam penelitian Borg \& Gall dapat dilihat pada gambar berikut.

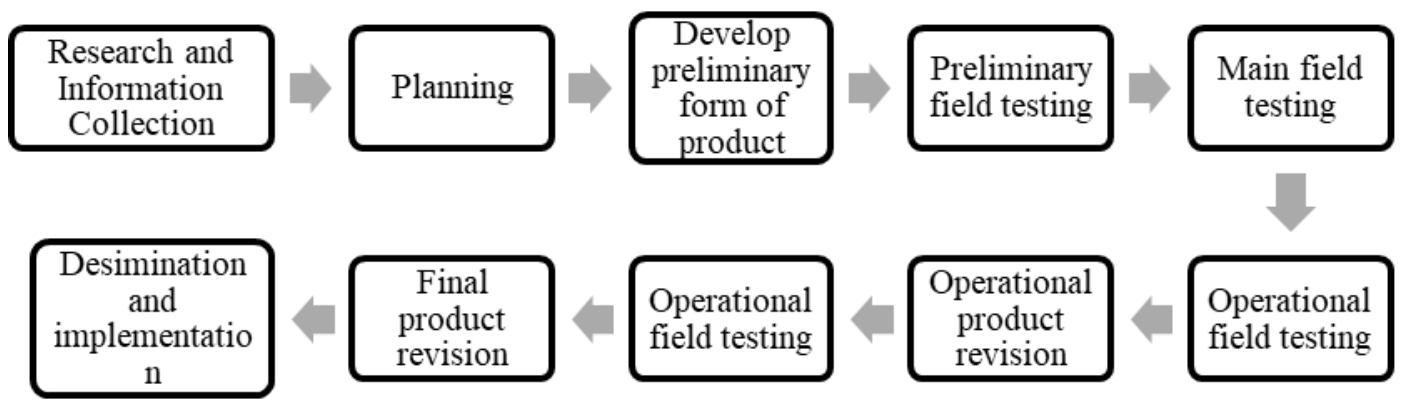

Gambar 1. Tahapan Penelitian Pengembangan Borg \& Gall

Pembelajaran menggunakan ILDF (Integratif Learning Design Framework) cocok digunakan pada masa Covid 19 dimana, pembelajaran harus dilakukan melalui daring atau online.

Tabel 1 Modul ILDF (Integratif Learning Design Framework)

\begin{tabular}{|l|l|}
\hline Tahapan & \multicolumn{1}{c|}{ Uraian Kegiatan Pembelajaran } \\
\hline Eksplorasi & $\begin{array}{l}\text { Menyelidiki konteks di mana kegiatan pembelajaran online akan dirancang dan } \\
\text { diimplementasikan yang terdiri dari menganalisis : }\end{array}$ \\
& $\begin{array}{l}\text { 1. Kebutuhan guru dan peserta didik } \\
\text { 2. Kesulitan saat mengajar dan belajar } \\
\text { 3. Teori dan strategi instruksional yang digunakan (mengidentifikasi masalah atau } \\
\text { kesenjangan yang ada) }\end{array}$ \\
& $\begin{array}{l}\text { 4. Faktor sosial, budaya dan organisasi yang dapat menjadi kendala dalam desain, } \\
\text { pengembangan dan implementasi proses pembelajaran }\end{array}$ \\
& $\begin{array}{l}\text { 6. Kepercayaan, sikap, bias, pengalaman, asumsi, dan filsafat pendidikan perancang } \\
\text { pembelajaran tersebut } \\
\text { mendukung }\end{array}$ \\
\hline Enachment yang tersedia, modul pedagogis serta strategi instruksional yang \\
1. Semua informasi yang dikumpulkan dalam tahap eksplorasi sebaiknya \\
ditindaklanjuti
\end{tabular}




\begin{tabular}{|c|c|}
\hline Tahapan & Uraian Kegiatan Pembelajaran \\
\hline & $\begin{array}{l}\text { menilai kekuatan dan kelemahan dari prototipe yang hasilnya digunakan untuk } \\
\text { merevisi / menyempurnakan prototipe (untuk meningkatkan efektivitas dan daya } \\
\text { tarik), terdiri dari : } \\
\text { a. Penilaian dari ahli } \\
\text { b. Penilaian dari setiap pemakai } \\
\text { c. Penilaian dari kelompok kecil siswa } \\
\text { d. Sumatif dilakukan setelah implementasi prototipe tersebut untuk mengukur } \\
\text { dampak dari prototipe pada proses pembelajaran }\end{array}$ \\
\hline Reflection & $\begin{array}{l}\text { 1. Berpikir kritis dari pengalaman yang diperoleh di keseluruhan proses mendesain } \\
\text { prototipe pembelajaran, terdiri dari : } \\
\text { a. Desain modul } \\
\text { b. Pelajaran } \\
\text { c. Kemungkinan aplikasi dari prototipe pembelajaran } \\
\text { 2. Semua yang dipelajari dan diperoleh dari keseluruhan proses dapat digunakan } \\
\text { untuk mendesain ulang pembelajaran yang lebih baik }\end{array}$ \\
\hline
\end{tabular}

(Dabbagh and Bannan-Ritland , 2005)

Penelitian dilakukan di Program Studi Pendidikan Teknik Mesin UNIMED pada matakuliah Perencanaan Pembelajaran dan Pengembangan di semester 3 (Ganjil) Tahun Akademik 2020/2021. Baik uji coba perorangan, ujicoba kelompok kecil, dan ujicoba utama dilakukan di Unimed. Pada tahap pengembangan modul pembelajaran, penentuan sasaran dalam hal ini adalah dosen, pakar pembelajaran, ahli bidang studi, dan mahasiswa yang menilai modul pembelajaran yang telah dikembangkan berdasarkan kriteria, sebagai berikut: (1) evaluasi pakar pembelajaran (expert judgement) ditentukan berdasarkan kepakaran yang dimilikinya, (2) evaluator yang melaksanakan evaluasi ditentukan berdasarkan pada kemampuan dosen dengan klasifikasi ahli bidang studi.

Pengumpulan data dalam penelitian dan pengembangan ini dikelompokkan menjadi tiga, yaitu studi pendahuluan, pengembangan, dan uji validasi. Dalam setiap tahap penelitian dipilih teknik pengumpulan data tertentu sesuai dengan tujuan masing-masing. Pada studi pendahuluan, dipilih teknik kuesioner/angket, observasi, dan dokumentasi, di samping kajian literatur (literature review). Secara umum, ketiga, teknik tersebut digunakan secara bersamaan dan saling melengkapi.

Analisis data dalam menguji keefektifan produk menggunakan analisis statistik. Untuk menganalisis perbedaan nilai pretes dan posttes kedua kelas digunakan uji t sampel (one sample $t$ test). Analisis data dilakukan dengan menggunakan aplikasi SPSS dengan pertimbangan agar data yang diberikan lebih tajam dan akurat.
Sebelum melakukan uji t, data dipastikan bersifat homogen dan berdistribusi normal. Untuk menguji normalitas, data yang diperoleh sesuai dengan hasil uji Shapiro dan Liliefors dalam SPSS. Data dikatakan normal jika hasil statistik menunjukkan angka $>0,05$. Sedangkan untuk menguji homogenitas, data diambil berdasarkan metode Levene's Test. Jika nilai yang diperoleh > 0,05 maka data dikatakan homogen.

Setelah diadakan uji normalitas dan homogenitas, maka nilai tes kedua kelas diuji dengan SPSS. Jika nilai signifikansi $<0,05$ berarti Ho ditolak (ada perbedaan yang signifikan antara nilai pretes dengan nilai postes) (Saragih, 2015:189).

Hasil yang telah diperolah dari uji $t$ sampel kemudian digunakan untuk mengetahui peningkatan pemahaman mahasiswa dengan menggunakan teknik analisis data gain-test dalam menghitung nilai gain $(g)$.

\section{HASIL PENELITIAN}

Validasi modul perencanaan dan pembelajaran ini merupakan proses kegiatan untuk menilai apakah rancangan produk berupa modul pembelajaran yang akan digunakan sebagai sumber belajar dalam proses pembelajaran, akan lebih efektif. Hal ini dilakukan, sebelum perangkat pembelajaran ini digunakan dalam proses pembelajaran berlangsung.

Modul perencanaan dan pembelajaran ini dilakukan validasi terlebih dahulu oleh dua orang pakar/ahli bidang studi. Setiap ahli/pakar diminta untuk menilai kelayakan modul perencanaan dan pembelajaran yang 
dikembangkan, sehingga dapat diketahui kelemahan dan kekuatannya. Validasi modul perencanaan dan pembelajaran ini setelah dilakukan penilaian terhadap komponen kelayakan, selanjutnya dilakukan revisi/perbaikan. Hasil dari revisian/perbaikan modul dikembangkan lagi untuk dijadikan modul yang siap digunakan oleh mahasiswa dalam proses pembelajaran. Modul perencanaan dan pembelajaran yang dikembangkan ini diorganisir terhadap penataan isi materi bahan ajar, sehingga dapat memudahkan mahasiswa belajar.

Tabel 2. Penilaian Ahli Media Pembelajaran pada Modul Perencanaan dan Pembelajaran

\begin{tabular}{|c|c|c|c|}
\hline No. & Indikator & $\%$ & Kriteria \\
\hline \multirow[t]{3}{*}{1.} & Ukuran Modul & & \\
\hline & a. Kesesuaian ukuran modul dengan standar ISO & 86,5 & SB \\
\hline & b. Kesesuaian ukuran dengan materi isi modul & 85.0 & SB \\
\hline \multirow[t]{10}{*}{2.} & Desain Sampul Modul (Cover) & & \\
\hline & $\begin{array}{l}\text { a. Penampilan unsur tata letak pada sampul muka, belakang dan } \\
\text { punggung secara harmonis memiliki irama dan kesatuan (unity) } \\
\text { serta konsisten }\end{array}$ & 65.5 & B \\
\hline & b. Menampilkan pusat pandang (center point) yang baik. & 68.5 & B \\
\hline & $\begin{array}{l}\text { c. Komposisi dan ukuran unsur tata letak (judul, pengarang, } \\
\text { ilustrasi, logo, dll) proporsional, seimbang dan seirama dengan } \\
\text { tata letak isi (sesuai pola). }\end{array}$ & & \\
\hline & d. Warna unsur tata letak harmonis dan memperjelas fungsi & 75.5 & B \\
\hline & $\begin{array}{l}\text { e. Ukuran huruf judul buku lebih dominan dan proporsional } \\
\text { dibandingkan ukuran buku, nama pengarang }\end{array}$ & & \\
\hline & f. Warna judul buku kontras dengan warna latar belakang & 80.5 & SB \\
\hline & g. Tidak menggunakan terlalu banyak kombinasi jenis huruf & 82.5 & SB \\
\hline & $\begin{array}{l}\text { h. Menggambarkan isi/ materi ajar dan mengungkapkan karakter } \\
\text { objek }\end{array}$ & 84.5 & SB \\
\hline & i. Bentuk, warna, ukuran, proporsi obyek sesuai dengan realita. & 80.0 & SB \\
\hline \multirow[t]{19}{*}{3.} & Desain Isi Modul: & & \\
\hline & a. Penempatan unsur tata letak konsisten berdasarkan pola & 80.5 & SB \\
\hline & b. Pemisahan antar paragraf jelas & 88.5 & SB \\
\hline & c. Bidang cetak dan margin proporsional & 78.5 & B \\
\hline & d. Marjin dua halaman yang berdampingan proporsional & 80.5 & SB \\
\hline & e. Spasi antara teks dan ilustrasi sesuai & 87.0 & SB \\
\hline & $\begin{array}{l}\text { f. Penempatan judul kegiatan belajar, sub judul kegiatan belajar, dan } \\
\text { angka halaman/ folio tidak mengganggu pemahaman }\end{array}$ & 88.5 & SB \\
\hline & $\begin{array}{l}\text { g. Penempatan ilustrasi dan keterangan gambar (caption) tidak } \\
\text { mengganggu pemahaman }\end{array}$ & 78.5 & B \\
\hline & $\begin{array}{l}\text { h. Penempatan hiasan/ ilustrasi sebagai latar belakang tidak } \\
\text { mengganggu judul, teks, angka halaman }\end{array}$ & 77.5 & B \\
\hline & $\begin{array}{l}\text { i. Penempatan judul, subjudul, ilustrasi, dan keterangan gambar } \\
\text { tidak mengganggu pemahaman }\end{array}$ & 80.5 & SB \\
\hline & j. Tidak menggunakan terlalu banyak jenis huruf & 78.5 & $\mathrm{~B}$ \\
\hline & $\begin{array}{l}\text { k. Penggunaan variasi huruf (bold, italic, all capital, small capital) } \\
\text { tidak berlebihan }\end{array}$ & 80.5 & SB \\
\hline & 1. Lebar susunan teks normal & 76.5 & $\mathrm{~B}$ \\
\hline & m. Spasi antar baris susunan teks normal & 80.5 & SB \\
\hline & n. Spasi antar huruf (kerning) normal & 86.5 & SB \\
\hline & o. Jenjang/ hierarki judul-judul jelas, konsisten dan proporsional & 82.5 & SB \\
\hline & p. Tanda pemotongan kata (hyphenation) & 68.0 & $\mathrm{~B}$ \\
\hline & q. Ilustrasi isi mampu mengungkap makna/ arti dari objek & 80.5 & SB \\
\hline & r. Bentuk akurat dan proporsional sesuai dengan kenyataan & 79.5 & B \\
\hline
\end{tabular}




\begin{tabular}{|l|l|c|c|}
\hline No. & \multicolumn{1}{|c|}{ Indikator } & $\%$ & Kriteria \\
\hline & s. Ilustrasi isi penyajian keseluruhan serasi & 76.5 & B \\
\hline & t. Kreatif dan dinamis ilustrasi isi & 78.5 & B \\
\hline
\end{tabular}

Keterangan: $\mathrm{B}=$ Baik dan $\mathrm{SB}=$ Sangat Baik

Tabel 3. Penilaian Ahli Materi Pembelajaran pada Modul perencanaan dan Pembelajaran

\begin{tabular}{|c|c|c|c|}
\hline No. & Indikator & $\%$ & Kriteria \\
\hline \multirow[t]{17}{*}{1} & Aspek Kelayakan Isi: & & \\
\hline & a. Kelengkapan materi sesuai Capaian Pembelajaran & 85.0 & SB \\
\hline & b. Keluasan materi & & \\
\hline & c. Kedalaman materi & 65.5 & B \\
\hline & d. Keakuratan konsep dan definisi & 68.5 & B \\
\hline & e. Keakuratan data dan fakta & 85.0 & SB \\
\hline & f. Keakuratan contoh dan kasus & 85.0 & SB \\
\hline & g. Keakuratan gambar, diagram, dan ilustrasi & 84.5 & SB \\
\hline & h. Keakuratan istilah-istilah & 80.5 & SB \\
\hline & i. Keakuratan notasi, simbol, dan ikon & 82.5 & SB \\
\hline & j. Keakuratan acuan pustaka & 84.5 & SB \\
\hline & k. Kesesuaian materi dengan perkembangan & 85.0 & SB \\
\hline & 1. Contoh dan kasus dalam dalam penggunakan & & \\
\hline & m. Gambar, diagram dan ilustrasi & 65.5 & $\mathrm{~B}$ \\
\hline & n. Kemutahiran pustaka & 68.5 & B \\
\hline & o. Mendorong rasa ingin tahu & 84.5 & SB \\
\hline & p. Menciptakan kemampuan bertanya tentang & 85.0 & SB \\
\hline \multirow[t]{12}{*}{2} & Aspek Penyajian: & 75.5 & $\mathrm{~B}$ \\
\hline & a. Konsistensi sistematika sajian dalam kegiatan belajar & 84.5 & SB \\
\hline & b. Keruntutan konsep penyajiannya & 85.0 & SB \\
\hline & $\begin{array}{l}\text { c. Contoh-contoh soal dalam setiap kegiatan belajar mendukung } \\
\text { penyajian }\end{array}$ & 65.5 & B \\
\hline & d. Soal latihan pada setiap akhir kegiatan belajar & 68.5 & B \\
\hline & e. Kunci jawaban soal latihan & 75.5 & B \\
\hline & f. Pengantar glosarium & 80.5 & SB \\
\hline & g. Daftar pustaka & 75.5 & $\mathrm{~B}$ \\
\hline & h. Rangkuman & 80.5 & SB \\
\hline & i. Keterlibatan mahasiswa dalam penyajian pembelajaran & 82.5 & SB \\
\hline & j. Ketertautan antar kegiatan belajar/sub kegiatan & 84.5 & SB \\
\hline & k. belajar/alenia secara runtut alur pikirnya & 80.0 & SB \\
\hline \multirow[t]{7}{*}{3} & Penilaian Bahasa: & & \\
\hline & a. Lugas & 80.5 & SB \\
\hline & b. Komunikatif & 88.5 & SB \\
\hline & c. Dialogis dan interaktif & 65.5 & $\mathrm{~B}$ \\
\hline & d. Kesesuaian dengan tingkat perkembangan belajar & 68.5 & B \\
\hline & e. Keruntutan dan ketepatan alur pikir & 75.5 & $\mathrm{~B}$ \\
\hline & f. Penggunaan istilah, simbol atau ikon & 80.5 & SB \\
\hline
\end{tabular}

Keterangan: $\mathrm{B}=$ Baik dan SB = Sangat Baik

Tabel 4. Respon Mahasiswa terhadap Modul perencanaan dan Pembelajaran

\begin{tabular}{|c|l|c|c|}
\hline No. & \multicolumn{1}{|c|}{ Indikator } & \% & Kriteria \\
\hline 1 & Aspek Tampilan: & & \\
\hline & $\begin{array}{c}|c| \\
\text { a. Teks atau tulisan pada modul ini mudah dibaca. }\end{array}$ & 86,72 & SB \\
\hline & $\begin{array}{l}\text { b. Gambar yang disajikan jelas atau tidak buram. } \\
\text { tidak terlalu sedikit) }\end{array}$ & 85.43 & SB \\
\hline
\end{tabular}




\begin{tabular}{|c|c|c|c|}
\hline & $\begin{array}{l}\text { d. Adanya keterangan pada setiap gambar yang disajikan dalam } \\
\text { modul ini. }\end{array}$ & 65.62 & $\mathrm{~B}$ \\
\hline & e. Gambar yang disajikan menarik. & 68.83 & $\mathrm{~B}$ \\
\hline & f. Gambar yang disajikan sesuai dengan materi & & \\
\hline \multirow[t]{13}{*}{2} & Apek Penyajian Materi: & & \\
\hline & $\begin{array}{l}\text { a. Modul ini menjelaskan suatu konsep menggunakan ilustrasi } \\
\text { masalah yang berkaitan }\end{array}$ & 75.94 & $\mathrm{~B}$ \\
\hline & b. Modul ini menggunakan contoh-contoh soal yang berkaitan & 80.15 & SB \\
\hline & $\begin{array}{l}\text { c. Penyajian materi dalam modul ini mendorong saya untuk } \\
\text { berdiskusi dengan teman-teman yang lain. }\end{array}$ & 82.44 & SB \\
\hline & $\begin{array}{l}\text { d. Penyajian materi dalam modul ini berkaitan dengan materi } \\
\text { matematika yang lain atau dengan mata pelajaran yang lain } \\
\text { dalam pemecahan masalah dan penerapannya. }\end{array}$ & 84.64 & SB \\
\hline & e. Saya dapat memahami materi dengan mudah. & 80.3 & SB \\
\hline & f. Materi yang disajikan dalam modul sudah runtut. & & \\
\hline & $\begin{array}{l}\text { g. Saya dapat mengikuti kegiatan belajar tahap demi tahap dengan } \\
\text { mudah. }\end{array}$ & 80.26 & SB \\
\hline & $\begin{array}{l}\text { h. Saya dapat dengan mudah memahami kalimat yang digunakan } \\
\text { dalam modul ini. }\end{array}$ & 88.63 & SB \\
\hline & $\begin{array}{l}\text { i. Tidak ada kalimat yang menimbulkan makna ganda dalam } \\
\text { modul ini. }\end{array}$ & 78.64 & $\mathrm{~B}$ \\
\hline & j. Saya dapat memahami pada modul ini. & 80.35 & SB \\
\hline & $\begin{array}{l}\text { k. Saya dapat memahami istilah-istilah yang digunakan dalam } \\
\text { modul ini. }\end{array}$ & 87.06 & SB \\
\hline & $\begin{array}{l}\text { 1. Contoh soal yang digunakan dalam modul ini sudah sesuai } \\
\text { dengan materi. }\end{array}$ & 88.54 & SB \\
\hline \multirow[t]{7}{*}{3} & Aspek Manfaat: & & \\
\hline & $\begin{array}{l}\text { a. Saya dapat memahami materi menggunakan modul ini dengan } \\
\text { mudah }\end{array}$ & 77.31 & $\mathrm{~B}$ \\
\hline & $\begin{array}{l}\text { b. Saya merasa lebih mudah belajar dengan menggunakan modul } \\
\text { ini }\end{array}$ & 80.44 & SB \\
\hline & c. Saya sangat tertarik menggunakan modul ini. & 78.65 & $\mathrm{~B}$ \\
\hline & $\begin{array}{l}\text { d. Dengan menggunakan modul ini saya lebih tertarik dalam } \\
\text { belajar. }\end{array}$ & 80.74 & SB \\
\hline & $\begin{array}{l}\text { e. Dengan adanya ilustrasi disetiap awal materi dapat memberikan } \\
\text { motivasi untuk mempelajari materi. }\end{array}$ & 76.32 & $\mathrm{~B}$ \\
\hline & f. Saya lebih rajin belajar dengan menggunakan modul ini & 80.23 & SB \\
\hline
\end{tabular}

Keterangan: B = Baik dan SB = Sangat Baik

\section{Hasil Uji Coba Terbatas Modul Pembelajaran}

Uji coba dalam skala terbatas terdiri dari 6 mahasiswa diambil berdasarkan kualifikasi kompetensi dengan karegori kurang, sedang, dan baik. Uji coba terbatas dilakukan. Penentuan uji coba didasarkan pada adanya kemungkinan kecenderungan perubahan dari setiap langkah secara signifikan yang mengarah pada keberhasilan guru dalam mengimplementasikan pembelajaran berbasis kompetensi sesuai tujuan pengembangan yang telah ditentukan, sehingga ditemukan bentuk modul pembelajaran yang dianggap memadai dan cocok.
Uji coba modul dalam skala terbatas ini mempunyai tujuan untuk mengetahui tingkat keterterapan modul, serta kendala-kendala yang dijumpai dalam penerapan modul. Dengan melakukan penilaian terhadap kelima aspek yang dirumuskan dalam setiap tahap uji coba, selanjutnya desain modul pembelajaran dilakukan perbaikan dan penyempurnaan. Hasil dari uji coba terbatas mendapatkan masukan yang berarti untuk dilakukan perbaikan dan pengembangan untuk dilakukan kembali uji coba utama.

Dari pelaksanaan uji coba terbatas dilakukan penilaian terhadap lima aspek seperti tersebut di atas, yaitu: (1) hasil kualitas 
pembelajaran, (2) hasil pelaksanaan pembelajaran, (3) hasil metode pembelajaran, (4) hasil penilaian mahasiswa terhadap desain modul pembelajaran, dan (5) hasil evaluasi belajar mahasiswa .

Tabel 5. Hasil Kualitas Pelaksanaan Pembelajaran pada Uji Coba Terbatas

\begin{tabular}{|c|c|c|}
\hline $\begin{array}{l}\text { Kriteria Penilaian terhadap } \\
\text { Penerapan Pelaksanaan Modul } \\
\text { pembelajaran }\end{array}$ & $\%$ & $\begin{array}{l}\text { Kri } \\
\text { teri } \\
\text { a }\end{array}$ \\
\hline $\begin{array}{lr}\text { A. } \text { Mudah dipahami } & \text { dan } \\
\text { dimengerti dalam pelaksanaan } \\
\text { pembelajaran } & \text { dengan } \\
\text { menggunakan } & \text { modul } \\
\text { pembelajaran } & \text { yang } \\
\end{array}$ & $\begin{array}{l}87, \\
65\end{array}$ & \multirow[t]{4}{*}{ SB } \\
\hline a Tethatasbangkan bagi Krswa Krite & ria3 & \\
\hline 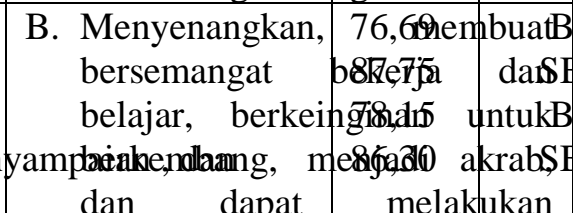 & $\begin{array}{c}86 \\
76\end{array}$ & \\
\hline $\begin{array}{l}\text { kerjasama dengan baik bagi } \\
\text { siswa. } \\
\text { C. Meningkatkan dalam belajar } \\
\text { dan bekerja, dan } \\
\text { meningkatkan kompetensi } \\
\text { siswa }\end{array}$ & & \\
\hline $\begin{array}{l}\text { Rata-rata penilaian } \\
\text { terhadap penerapan } \\
\text { pembelajaran }\end{array}$ & $\begin{array}{c}87 \\
50\end{array}$ & $\mathrm{SB}$ \\
\hline
\end{tabular}

Kualitas Pembelajaran Pada Hasil Uji Coba Tethatasbangkan bagi \&rswa Kriterił3

A. Pengorganisasian Pembelajaran

B. Penyampaian Pembelajaran

C. Pengelolaan Pembelajaran

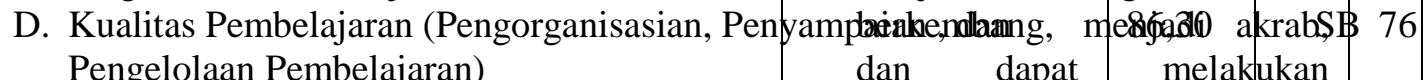

Keterangan: $\mathrm{B}=$ Baik dan SB = Sangat Baik

Hasil Penilaian Mahasiswa terhadap Modul Pembelajaran dalam Pendidikan pada Uji Coba Terbatas

Berdasarkan data hasil survei melalui angket yang dilakukan terhadap proses pelaksanaan pembelajaran dengan menggunakan desain modul yang dikembangkan terhadap penilaian mahasiswa.

Keterangan: B = Baik dan SB = Sangat Baik

Tabel 6. Hasil Penilaian Mahasiswa terhadap Pelaksanaan Pembelajaran dengan Menggunakan Modul Pembelajaran pada Uji Coba Terbatas

\begin{tabular}{|l|l|l|}
\hline $\begin{array}{l}\text { Kriteria Penilaian terhadap } \\
\text { Penerapan Pelaksanaan Modul } \\
\text { pembelajaran }\end{array}$ & $\%$ & $\begin{array}{l}\text { Kri } \\
\text { teri } \\
\text { a }\end{array}$ \\
\hline
\end{tabular}

Peningkatan kemampuan Pembelajaran dan Perencanaan Pengembangan yang menggunakan modul pembelajaran menggunakan ILDF dibandingkan dengan modul konvensional melalui perbandingan nilai mean tes awal, tes akhir dan N-gain antara kelas eksperimen dan kelas kontrol ditunjukkan pada Gambar 1.

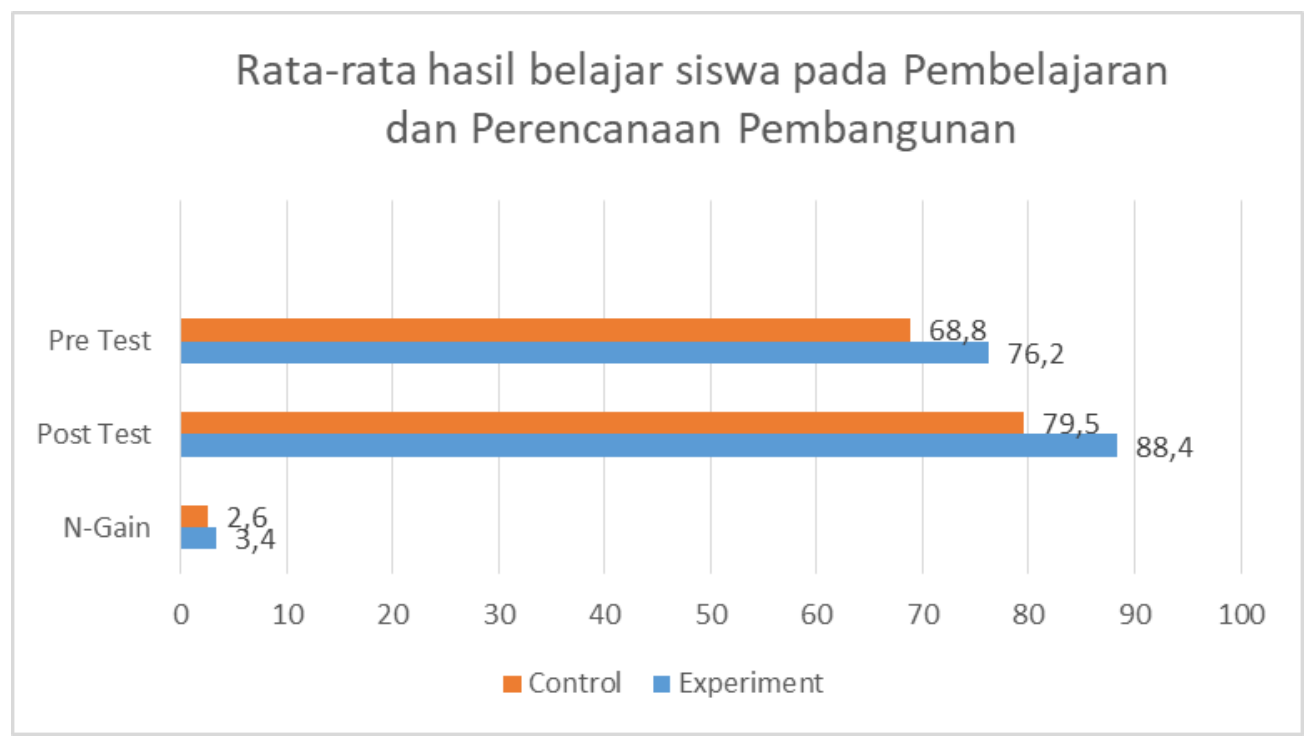

Gambar 1. Perbandingan nilai rata-rata pretes, postes, dan n-gain modul pembelajaran ILDF terhadap modul konvensional 
Uji operasional yang dilakukan secara bersiklus melalui empat tahapan utama, yaitu perencanaan, pelaksanaan, observasi, dan refleksi. Uji operasional lebih bersifat perbaikan terhadap modul sebelum dilakukan uji eksperimen. Dalam uji operasional ini terdiri dari dua siklus. Dalam setiap siklus terdiri dari tiga tindakan dan satu pertemuan untuk evaluasi. Data pada setiap siklus diambil menggunakan lembar observasi terhadap unjuk kerja dan hasil kerja selama proses pembelajaran. Item penilaian atau pengamatan dikembangkan berdasarkan indikator-indikator dalam menggunakan alat dan bahan.

Penelitian dan pengembangan pada tahap pertama ini telah dilakukan: (1) analisis kebutuhan terhadap Modul pembelajaran berbasis integrative learning design frame work, (2) kebutuhan terhadap pengembangan media dan bahan ajar pembelajaran, (3) perencanaan/penyusunan dan pengembangan modul pembelajaran, meliputi; merumuskan tujuan pembelajaran, menganalisis kendala dan karakteristik bidang studi, menyusun silabus dan rencana pelaksanaan semester (RPS), menganalisis karakteristik mahasiswa, merumuskan strategi pembelajaran meliputi; kegiatan pra pembelajaran, penyajian informasi, peran serta mahasiswa, pemberian tes, dan kegiatan tindak lanjut, merancang kebutuhan waktu dan sumber belajar, merancang alat evaluasi, (2) pelaksanaan pembelajaran, dan (3) evaluasi pembelajaran. Hasil temuan ini akan menjadi bahan pada tahap kedua.

Hasil temuan pada tahap pertama ini adalah: (1) modul pembelajaran berbasis integrative learning design frame work yang cocok dan tepat yang akan dikembangkan dan media pembelajaran yang dapat memberi kemudahan belajar mahasiswa, (2) menemukan kompetensi yang harus dimiliki oleh lulusan sesuai pasar kerja, (3) menemukan materi kompetensi perencanaan pembelajaran, (4) menemukan strategi pembelajaran dengan modul pembelajaran berbasis integrative learning design frame work bagi mahasiswa, (5) mengembangkan pelatihan berdasarkan kompetensi (competency based training), (6) mengembangkan modul dan media pembelajaran dan lembar kerja mahasiswa berbasis kompetensi berorientasi produksi, (7) menemukan pola manajemen pembelajaran yang mendukung peningkatan kompetensi mahasiswa. \begin{tabular}{llll}
\multicolumn{2}{c}{ Rencana tahap } & kedua (II) & adalah \\
Melakukan kajian & terhadap & Modul \\
pembelajaran & berbasis & integrative & learning
\end{tabular} design frame work yang dikembangkan, kompetensi dan materi pembelajaran yang telah ditemukan pada tahap pertama. Modul pembelajaran berbasis integrative learning design frame work pada mahasiswa dilakukan uji coba dan validasi ahli/pakar di bidangnya. Dengan demikian tahap kedua ini akan dilakukan validasi modul pembelajaran, media pembelajaran, dan uji coba modul serta media pembelajaran pada bidang keahlian teknik pemesinan.

Penelitian pada tahap selanjutnya yaitu tahap II, diharapkan akan dapat menghasilkan dan mengembangkan modul pembelajaran berbasis integrative learning design frame work. Modul pembelajaran berbasis integrative learning design frame work mampu memberikan pola strategi pembelajaran yang berbeda sesuai dengan tingkat dan perkembangan kognitif mahasiswa, serta penggunaan teknologi yang menyertai dalam proses pembelajaran berlangsung. Kemampuan ditekankan pada kemampuan tingkat tinggi, yaitu pada C4 sampai dengan C6 sesuai dengan kemampuan kognitif mahasiswa dalam upaya meningkatkan penguasaan terhadap matakuliah perencanaan pembelajaran. Melalui serangkaian tahap pengembangan dan validasi ahli serta uji coba pada tahap II akan dapat menghasilkan modul yang utuh dan yang dapat digunakan dalam pengembangan proses pembelajaran dengan baik pada mahasiswa.

Uji coba modul dilakukan dalam tahap kedua ini melalui uji coba perseorangan, uji coba kelompok kecil, dan uji coba lapangan dengan beberapa mahasiswa, disamping itu juga dilakukan uji ahli terhadap bidang studi, ahli rancangan pembelajaran. Dari hasil uji coba diharapkan diperoleh masukan sebagai bahan penyempurnaan draft modul yang diuji cobakan. Hasil kajian pada tahap kedua ini adalah desain Modul pembelajaran berbasis integrative learning design frame work pada mahasiswa. Hasil uji coba dan validasi dari ahli untuk selanjutnya dilakukan revisi pada masing-masing aspek dan komponen Modul pembelajaran berbasis integrative learning design frame work untuk penyempurnaan modul pembelajaran yang dikembangkan. Pada tahap ke dua ini juga dilakukan uji coba melalui: review ahli bidang studi, review ahli design pembelajaran, uji coba perorangan, uji 
coba kelompok kecil, dan uji coba lapangan/utama.

Uji coba modul pembelajaran berbasis integrative learning design frame work dilakukan dalam tahap kedua ini melalui uji coba perseorangan, uji coba kelompok kecil, dan uji coba lapangan dengan beberapa mahasiswa, disamping itu juga dilakukan uji ahli terhadap bidang studi, ahli rancangan pembelajaran. Dari hasil uji coba diharapkan diperoleh masukan sebagai bahan penyempurnaan draft modul yang diuji cobakan. Hasil kajian pada tahap kedua ini adalah modul pembelajaran berbasis integrative learning design frame work untuk meningkatkan kualitas pembelajaran dan karakter mahasiswa.

Hasil uji coba dan validasi dari ahli untuk selanjutnya dilakukan revisi pada masingmasing aspek dan komponen modul pembelajaran berbasis integrative learning design frame work untuk penyempurnaan modul pembelajaran yang dikembangkan.

Perencanaa pembelajaran dan pengembangan meruakan matakuliah bidang pendidikan di jurusan pendidikan teknik mesin dan merupakan salah satu wujud dari pembentukan komunitas belajar yang harus di kuasai bagi pengajar/guru dalam pelaksanaan pembelajaran. Terbentuknya komunitas belajar merupakan sarana untuk pengembangan diri setiap guru. Modul pembelajaran berbasis integrative learning design frame work akan meningkatkan rasa kebersamaan dan kolegialitas antara sesama mahasiswa calon guru dalam mempraktekkan dengan menggunakan karakter sebagai bagian penanaman dalam pembelajaran dan aspek konstruktivistik selalu ditekankan kepada mahasiswa agar dapat mengembangkan dan mengngonstruk pengetahuan dan wawasannya untuk lebih baik lagi.

Dosen harus terus berupaya melakukan pembenahan dalam dunia pendidikan dengan cara belajar sepanjang hayat untuk dapat mengimplementasikan tujuh elemen pendekatan kontekstual. Adapun rincian ketujuh elemen tersebut, yaitu: (1) memberi kesempatan peserta didik untuk bertanya (questioning), (2) menerapkan penilaian autentik saat proses pembelajaran (authentic assessment), (3) melatih peserta didik untuk menjadi modul bagi temannya (moduling), (4) melatih peserta didik untuk melakukan refleksi (reflection), (5) membentuk masyarakat belajar dengan meminta peserta didik belajar kelompok(learning community), (6) melatih peserta didik untuk menyusun konsep pembelajaran sendiri (constructivism), dan (7) menemukan konsep yang akan dipelajarinya(inquiry).

Rata-rata hasil belajar kelompok yang pembelajarannya menggunakan modul pembelajaran experintial berbasis kerangka kerja desain pembelajaran integratif lebih tinggi jika dibandingkan dengan hasil belajar yang dilaksanakan dengan pembelajaran konvensional.

Perencanaan pembelajaran dan pengembangan merupakan salah satu bentuk pembentukan komunitas belajar yang harus dikuasai guru dalam melaksanakan pembelajaran. Pembentukan komunitas belajar merupakan sarana pengembangan diri setiap guru. Modul pembelajaran eksperimental berbasis kerangka kerja desain pembelajaran integratif akan meningkatkan rasa kebersamaan dan kolegialitas antar sesama calon guru dalam praktek dengan menggunakan karakter sebagai bagian dari pembinaan dalam pembelajaran dan aspek konstruktivis selalu diutamakan pada siswa sehingga dapat berkembang dan berkembang. membangun pengetahuan dan wawasan mereka menjadi lebih baik.

Pelaksanaan pembelajaran dengan menerapkan modul pembelajaran eksperiensial berbasis kerangka kerja desain pembelajaran integratif diharapkan setiap siswa siap untuk mengubah pola pikir seperti yang telah dilakukan oleh penulis guna mendapatkan ideide yang berharga dalam proses pembelajaran. Dosen sebagai ujung tombak pendidikan diharapkan lebih terbuka, mau menerima setiap perubahan dunia pendidikan dengan berusaha meningkatkan pembelajaran yang telah dilakukan.

Hasil penelitian juga didukung oleh peneliti Jannti (2016) yang menunjukkan bahwa model pembelajaran Experiential Kolb dapat lebih meningkatkan kemampuan menjelaskan fenomena fisik dibandingkan pembelajaran konvensional. Hasil analisis respon siswa menunjukkan bahwa siswa memiliki respon yang positif terhadap penerapan modul pembelajaran Experiential Kolb.

Model pembelajaran yang menggunakan ILDF dalam Learning and Development Planning dalam setiap pertemuan selalu mengaitkan pengalaman siswa dengan hal-hal yang dapat dijelaskan secara fisik, dimana 
siswa menunjukkan fenomena yang dialaminya dalam kehidupan sehari-hari, hal ini sejalan dengan penelitian Dale (2013) yang menunjukkan bahwa siswa dapat mengetahui lebih banyak informasi tentang apa yang mereka "lakukan". Edgar Dale juga menjelaskan bahwa experiential learning merupakan pengalaman yang diperoleh siswa sebagai hasil dari aktivitasnya sendiri, siswa berhubungan langsung dengan objek yang akan dipelajari.

Penerapan moduel pembelajaran eksperimen dapat digunakan sebagai model pembelajaran alternatif untuk mengubah dan meningkatkan pemahaman konseptual siswa, perubahan konsepsi siswa, digunakan sebagai kegiatan pembelajaran yang menunjang proses pembelajaran itu. menyenangkan, ilmiah, dan memberikan hasil pemahaman. sebuah konsep yang baik, sejalan dengan penelitian yang dilakukan oleh Alamanda (2019). Didukung oleh penelitian Manolas (2005) menunjukkan bahwa modul pembelajaran Experiential Kolb dapat merangsang siswa untuk memilih pembelajaran dan menantang mereka untuk membangun keterampilan dalam berpikir yang efektif dan pemecahan masalah.

Penelitian yang sama yang dilakukan oleh Rahman (2009) mengungkapkan bahwa penerapan model pembelajaran eksperiensial dapat meningkatkan kemampuan penalaran deduktif siswa (Samsudin, 2016). Penerapan modul experiential learning dapat meningkatkan hasil belajar kognitif dan kemampuan pemecahan masalah.

Ariani (2018), dalam penelitiannya, menunjukkan bahwa model ini berfokus pada blended learning dan bukan pada model pembelajaran online, karena Blended Learning dapat memberikan pengalaman belajar tatap muka yang dipadukan dengan berbagai modalitas pembelajaran dan konteks aplikasi berbasis teknologi. Model Blended Learning yang dirancang khusus dengan menerapkan Experiential Learning. Model yang ditinjau adalah Model APKL, yaitu model yang dimaksudkan untuk mengembangkan blended learning dengan menerapkan experiential learning. Sementara itu, Syafriani (2013) mengatakan bahwa penerapan model pembelajaran eksperiensial dengan pendekatan inkuiri dapat meningkatkan keterampilan proses sains.

\section{PENUTUP}

Ahli Desain Pembelajaran pada buku ajar perencanaan pembelajaran berbasis integrative learning design framework layak untuk digunakan dalam pembelajaran dan Modul Perencanaan dan Pembelajaran layak digunakan dalam proses pembelajaran pada mata kuliah perencanaan dan pengembangan pembelajaran

Kualitas pelaksanaan pembelajaran pada uji coba terbatas pada kriteria buku ajar perencanaan pembelajaran berbasis integrative learning design framework yang dikembangkan sangat baik dan layak digunakan dalam proses pembelajaran. Penilaian Siswa terhadap Pelaksanaan Pembelajaran Uji Coba Terbatas layak digunakan dalam proses pembelajaran

Berdasarkan data dan analisis hasil penelitian yang telah dilakukan terhadap penerapan buku ajar perencanaan pembelajaran berbasis integrative learning design framework untuk meningkatkan kemampuan Pembelajaran dan Perencanaan Pembangunan, maka dapat disimpulkan bahwa penerapan buku ajar perencanaan pembelajaran berbasis integrative learning design frameworkdapat dikatakan signifikan. lebih tinggi dari modul konvensional.

Mahasiswa memberikan respon yang positif terhadap penerapan buku ajar perencanaan pembelajaran berbasis integrative learning design framework.

\section{DAFTAR PUSTAKA}

Alamanda, G.C. (2019). Penerapan Modul Pembelajaran Experiental Learning Terhadap Perubahan Konseptual Siswa Pada Materi Sifat-Sifat Cahaya. ISSN 1412-565 X.

Ariani, D. Diana. (2018). Modul Blended Learning Dengan Menerapkan Experiential Learning. Jurnal Pembelajaran Inovatif, 1(2), 8-15. DOI: https://doi.org/10.21009/JPI.012.02 http://journal.unj.ac.id/unj/index.php/jpi.

Borg, W R \& Gall, M D. (2005). Educational research: an introduction, Fourth Edition. New York: Longman. Inc.

Dabbagh, Nada. (2005). Online Learning: Concepts, Strategies, and Application. New Jersey: Pearson Education Inc.

Dale, E.A. (2013). Audiovisual methods in teaching. (6d ed.). New York: Holt, Rinehart and Winston.

Hamalik, Oemar. (2001). Proses Belajar Mengajar. Jakarta : Bumi Aksara. 
Holmqvist, M. (2014). Experiential Learning Processes of Exploitation and Exploration Within and Between Organizations: An Empirical Study of Product Development. Organization Science, 15(1), 70-81.

Jannti, Eidelweis Dewi. (2026). Modul Pembelajaran Experiential Kolb Untuk Meningkatkan Kemampuan Menjelaskan Fenomena Fisis Pada Konsep Optik. Grafiti: Jurnal Ilmiah Penelitian dan Pembelajaran Fisika. 2(2) ISSN 2442515x, e-ISSN 2528-1976 http://jurnal.untirta.ac.id/index.php/Gravi ty

Kolb, A. Y., \& Kolb, D. A. (2015). Learning Styles and Learning Spaces: Enhancing Experiential Learning in Higher Education. Academy of Management Learning \& Education, 4(2), 193-212.

Kolb, David. (1984). Experiental Learning. New jersey: Prentice Hall Inc.

Lestari, N. W. dkk. (2014). Pengaruh Modul Experiential Learning TerhadapKeterampilan Berpikir Kritis dan Motivasi Berprestasi Siswa.
Singaraja. Universitas Pendidikan Ganesha.

Manolas, E.I. (2002). “Kolb's Experiential Learning Modul: Enlivening Physics Courses in Primary Education". The Internet TESL Journal. 3,(9). Di akses 16 Desember 2019

Rahman, Andi. (2009). Penerapan Modul Pembelajaran Experiential Learning dalam Upaya Meningkatkan Kemampuan Penalaran Deduktif Siswa SMA. Bandung: Universitas Pendidikan Indonesia. Tidak diterbitkan.

Samsudin, A. (2016). Pengembangan Dual Conditioned Learning Modul-Utilizing Multimode Teaching (Dclm-Umt) Untuk Mengoptimalkan Pemahaman Konsep Fisika Dasar Calon Guru (Doctoral dissertation, Universitas Pendidikan Indonesia).

Syafriani, S. (2013). Penerapan Modul Pembelajaran Berbasis Pengalaman Dengan Pendekatan Inkuiri Pada Materi Cahaya Untuk Meningkatkan. Jurnal Pendidikan, 3(2), 50-68. 